\title{
THE EFFECT OF METHANOGENIC INHIBITOR FEED ON PROPIONIC ACID AND LAMB MEAT CHEMICAL QUALITY
}

\author{
E. H. B. Sondakh ${ }^{1,2}$, L. M. Yusiati ${ }^{1}$ H. Hartadi ${ }^{1}$ and E. Suryanto ${ }^{1}$ \\ ${ }^{1}$ Faculty of Animal Science and Technology, Gadjah Mada University, \\ Jl. Fauna 3 Kampus UGM Bulaksumur Yogyakarta - Indonesia \\ ${ }^{2}$ Permanent Address: Faculty of Animal Science, Sam Ratulangi University, \\ Jl. Kampus Kleak Manado-Indonesia 95115 - Indonesia \\ Corresponding E-mail: erwin_sondakh@yahoo.com
}

Received May 04, 2012; Accepted July 28, 2012

\begin{abstract}
ABSTRAK
Tujuan dari penelitian ini adalah untuk mengetahui pengaruh dari medium chain fatty acids (MCFA) terhadap asam propionat dan kualitas kimia daging domba. Ada tiga perlakuan dalam penelitian ini yakni R1 adalah komposisi pakan tanpa MCFA, sementara R2 dan R3 adalah komposisi pakan yang masing-masing mengandung MCFA $1,0 \%$ dan $1,5 \%$. Pada penelitian ini digunakan dua belas ekor domba berumur satu tahun dengan berat hidup 16-17 kg sebagai ternak percobaan dan dipelihara selama tiga bulan. Setelah penelitian diambil cairan rumen untuk dianalisa asam propionat, kemudian dipotong dan diambil karkasnya untuk dianalisa komposisi kimia daging, kolesterol dan asam-asam lemak daging. Hasil penelitian menunjukkan bahwa pakan penghambat metanogenik dengan kandungan MCFA 1,0 $1,5 \%$ dapat digunakan pada pakan domba dan hasilnya adalah asam propinat cairan rumen meningkat 29,59-36,11\%. Kolesterol daging menurun 7,14-10,06\%. Untuk komposisi asam lemak daging, asam lemak tidak jenuh meningkat 9,05-17,96\%, sedangkan asam lemak jenuh daging menurun 6,59$11,88 \%$.
\end{abstract}

Kata kunci: komposisi kimia, asam-asam lemak, MCFA, asam propionat, domba

\section{ABSTRACT}

This study aimed to determine the effect of medium chain fatty acids (MCFA) on propionic acids and lamb meat chemical quality. The treatment given was R1: feed without medium chain fatty acids (MCFA), while R2 dan R3 were the feed contained $1.0 \%$ and $1.5 \%$ of MCFA, respectively. The twelve heads of lambs yearling weight of 16-17 kg were used as materials. Biological trial was done for three months and then was slaughtered. Before being slaughtered, the animal was taken rumen fluid to be analyzed for propionic acid. The carcass was sampled to be analyzed for chemical composition, cholesterol and fatty acids content. This study showed that methanogenic inhibitor feed with $1.0-1.5 \%$ MCFA could be used as sheep feed, and the results: the propionic acid content in rumen increased 29.59 - 36.11\%. The cholesterol content decreased 7.14-10.06\%. For the meat fatty acids composition, unsaturated fatty acids increased $9.05-17.96 \%$. while saturated fatty acid decreased $6.59-11.88 \%$.

Keywords: chemical composition, fatty acids, MCFA, propionic acid, lamb

\section{INTRODUCTION}

Global warming is an issue that can interfere with the development of animal husbandry. Farms are considered as the cause of accumulation of these gases as environmental contaminants. The world's environment showed position the livestock sector as the largest contributor to green house gases (GHG). As most of the gas accumulating in the atmosphere that comes from the livestock sector is methane gas.
Inhibit the production of methane in the rumen was supposed to be done to respon global challenge of environment. Inhibition of methane production in the rumen resulting in changes in volatile fatty acids, especially propionic acid. Hydrogen $\left(\mathrm{H}_{2}\right)$ which is not formed into methane will be used for the formation of propionic acid. So, the inhibition of methane that will enhance the production of propionic acid.

In this study, the coconut cake was used as a 
source of medium chain fatty acid (MCFA) which can inhibit the production of methane, resulting in the increase of propionic acid production. In chemical process, propionic acid could minimize rumen biohydrogenation, making unsaturated fatty acid lead to small intestine without experiencing process of rumen hydrogenation (Marmer et al., 1985; Gilka et al., 1989). Meat quality is also influenced by the availability of sufficient propionic acid, the sufficient propionic acid content cause unsaturated fatty acid content in meat increases.

The objectives of this study were to evaluate the effect of medium chain fatty acids (MCFA) on propionic acid and the lamb meat chemical quality.

\section{MATERIALS AND METHODS}

The animals used were twelve heads of male yearling lamb having body weight of $16-17 \mathrm{~kg}$ that were divided into the groups and reraed in individual cages equipped with place for feed and drink.

Three treatments used in this experiment were, R1: elephant grass $60 \%$, soy bean cake $23 \%$, rice bran $17 \%$, without coconut cake; R2 : elephant grass $60 \%$, soy bean cake $20 \%$, rice bran $6 \%$ and coconut cake 14\%; R3: elephant grass $60 \%$, soy bean cake $17 \%$, rice bran $2 \%$ and coconut cake $21 \%$. The feed of treatment containing MCFA $0 \%, 1.0 \%$ and $1.5 \%$ in a row for R1, R2 and R3. This research was done with four replications.

The treatment and nutrient composition are presented in Table 1. Biological trial was done in 3 months. After feeding treatment for three months, rumen fluid was taken for analysis of propionic acid content (Doreau et al., 1993), and then the animals were slaughtered. Muscle samples were taken from the Longissimus dorsi for moisture, crude protein, crude fat, cholesterol and fatty acids composition. Moisture was determined by air drying (AOAC, 2005). Crude protein content was calculated by converting the nitrogen content, determined by the Kjeldahl method $(6.25 \times \mathrm{N})$ (AOAC, 2005), crude fat by Soxhlet extraction using diethyl ether (AOAC, 2005), cholesterol - using Leibermann and Burchard Method Procedure (Plumer,1988) and meat fatty acids composition (AOAC, 2005).

\section{Data Analysis}

Data were analyzed using one-way ANOVA and differences between average of treatment were continued by Duncan's Multiple Range Test (Steel and Torrie, 1989).

\section{RESULTS AND DISCUSSION}

\section{Propionic acid}

Rumen propionic levels in the study increased. Feed containing MCFA 1.0 to $1.5 \%$ could increase the propionic acid in rumen fluid. The raise of propionate causing methane amount in rumen declined (Christophersen et al., 2008). The linkage between propiogenic and methanogenic in competition is to get hydrogen $\left(\mathrm{H}_{2}\right)$. According to Martinko and Madigan (2005), propionic acid is formed from two pathways through the acrylate and succinate. Both of these two pathways in the form of propionic always need hydrogen.

\section{The chemical composition of lamb}

The results of research showed that the addition of coconut cake as methanogenic suppressing agent in the diet were not significantly different on moisture content of meat (Table 2). The moisture in this research varied at $71.92-72.95 \%$. Soeparno (2005) reported that the moisture in meat was $68-75 \%$, meanwhile Lawrie (1979) also stated that meat moisture ranged 68$80 \%$. Differences in moisture content could be influenced by environmental and genetic factors (Berg and Butterfield, 1976). Several authors had mentioned that moisture had an inverse relationship on the fat content of meat (Sheridan et al., 2003; Lee et al., 2008; Santos et al., 2008; Madrugan et al., 2005).

The results of research showed that the addition of coconut cake as methanogenic suppressing agent in the diet did not affect on crude protein of meat (Table 2). The crude protein content in this research (R1, R2 and R3) was similar. The crude protein content of meat in this research varied at $20.84-21.33 \%$. Crude protein levels were still within the range as reported by Soeparno (2005) that crude protein content of lamb varied at $16-22 \%$. Meanwhile, Geay et al. (2001) stated that protein of meat ranged at 17$22 \%$. No difference on crude protein of lamb given methanogenic inhibitor feed caused due to similar growth. According to Sherdian et al. (2003) the difference in energy level did not affect the protein content of meat.

The results of research indicated that feed 
Table 1. Composition of Experimental Rations

\begin{tabular}{|c|c|c|c|}
\hline \multirow{3}{*}{ Nutrient Composition } & \multicolumn{3}{|c|}{ Treatments } \\
\hline & \multirow{2}{*}{$\begin{array}{c}\text { No Methanogenic } \\
\text { Inhibitor }\end{array}$} & \multicolumn{2}{|c|}{ Methanogenic Inhibitor } \\
\hline & & $\mathrm{R} 2$ & R3 \\
\hline Elephant grass (\%) & 60.00 & 60.00 & 60.00 \\
\hline Rice bran(\%) & 17.00 & 6.00 & 2.00 \\
\hline Soybean cake $(\%)$ & 23.00 & 20.00 & 17.00 \\
\hline Coconut cake $(\%)$ & 0.00 & 14.00 & 21.00 \\
\hline Crude Protein $(\%)$ & 17.08 & 17.28 & 17.01 \\
\hline Crude Fat (\%) & 5.93 & 5.07 & 5.27 \\
\hline Crude Fiber (\%) & 23.27 & 23.29 & 23.41 \\
\hline Nitrogen Free Extract (\%) & 36.10 & 36.11 & 37.04 \\
\hline $\operatorname{Ash}(\%)$ & 10.46 & 9.84 & 9.96 \\
\hline MCFA in feed $(\%)$ & 0.00 & 1.00 & 1.50 \\
\hline
\end{tabular}

Table 2. Propionic Acid and $\mathrm{pH}$ in Rumen Fluid of Lamb Obtained Methanogenic Inhibitor Feed

\begin{tabular}{lccc}
\hline \multirow{2}{*}{ Variable } & \multicolumn{3}{c}{ Treatments } \\
\cline { 2 - 4 } & $\mathrm{R} 1$ & $\mathrm{R} 2$ & $\mathrm{R} 3$ \\
\hline Propionic acid $(\mu \mathrm{mol})$ & $2.07 \pm 0.36^{\mathrm{a}}$ & $2.94 \pm 0.23^{\mathrm{b}}$ & $3.24 \pm 0.39^{\mathrm{b}}$ \\
$\mathrm{pH}$ & $6.82 \pm 0.07$ & $6.76 \pm 0.07$ & $6.73 \pm 0.06$ \\
\hline
\end{tabular}

Different superscript at the same row indicate differ significantly $(\mathrm{P}<0.05)$

treatment using coconut cake of MCFA source as methanogenic inhibitive agent did not affect meat fat content. In this study, fat level of meat varied at $5.12-5.22 \%$. These results are still in range of meat fat content according to Forest et al. (1975) that was $1.5-13 \%$. Differences in lipid levels could be caused by the variations in growth patterns of carcass that consisted of bone, muscle and fat, besides it was also influenced by other factors such as genotype and physiological status of livestock (Soeparno, 2005). In general, reduction in muscular activity would increase fat deposition in muscular tissue, whereas intramuscular fat was widely affected by heredity factors (Forest et al., 1975).

The meat cholesterol levels decreased when the feeding was supplemented by MCFA. Meat cholesterol content in treatment R1 was found sufficiently higher than treatment R2 and R3. There was reduction approximately $7.14 \%$ when feed was given with coconut cake with $1.0 \%$ of MCFA content than without coconut cake. It indicated that feed containing coconut cake as much as $14 \%$ could reduce cholesterol content of lamb. In rumen digestion, MCFA content of coconut cake played a vital role in reducing methane production (Machmuler et al., 2006), affecting increase of propionate acid production. According to Duckett et al. (1992), propionic acid did not affect total fat and crude fat, but it could reduce cholesterol level. Furthermore, Duckett et al. (1992) stated that about 27 carbon chains of cholesterol were derived from acetate acid. Propionic could reduce acetate availability 
Table 3. Chemical Composition of Sheep Meat

\begin{tabular}{lccc}
\hline \multirow{2}{*}{ Variable } & \multicolumn{3}{c}{ Treatments } \\
\cline { 2 - 4 } & \multicolumn{1}{c}{$\mathrm{R} 1$} & $\mathrm{R} 2$ & $\mathrm{R} 3$ \\
\hline Moisture (\%) & $71.92 \pm 0.38$ & $72.60 \pm 0.09$ & $72.95 \pm 0.42$ \\
Crude Protein (\%) & $21.06 \pm 0.83$ & $21.33 \pm 0.25$ & $20.84 \pm 0.52$ \\
Crude Fat (\%) & $5.22 \pm 0.49$ & $5.18 \pm 0.63$ & $5.12 \pm 0.32$ \\
Cholesterol (mg/100g) & $77.00 \pm 3.90^{\mathrm{a}}$ & $71.50 \pm 2.60^{\mathrm{b}}$ & $69.25 \pm 3.30^{\mathrm{b}}$ \\
\hline
\end{tabular}

Mean with different superscripts at the same row indicate differ significantly $(\mathrm{P}<0.05)$

Table 4. Fatty Acids Content of Lamb

\begin{tabular}{lccc}
\hline \multirow{2}{*}{ Fatty Acid (\%) } & \multicolumn{3}{c}{ Treatments } \\
\cline { 2 - 4 } C-14 & $2.78 \pm 0.57$ & $R 2$ & R3 \\
C-16 & $15.04 \pm 0.32$ & $14.13 \pm 0.64$ & $14.35 \pm 0.56$ \\
C-16 (1) & $1.84 \pm 0.42$ & $1.83 \pm 0.15$ & $1.09 \pm 0.70$ \\
C-18 & $12.12 \pm 0.81^{\mathrm{a}}$ & $11.12 \pm 1.26^{\mathrm{b}}$ & $10.29 \pm 0.27^{\mathrm{c}}$ \\
C-18 (1) & $24.23 \pm 1.14^{\mathrm{a}}$ & $27.00 \pm 1.99^{\mathrm{b}}$ & $30.60 \pm 0.62^{\mathrm{c}}$ \\
C-18 (2) & $4.02 \pm 0.20^{\mathrm{a}}$ & $4.16 \pm 0.21^{\mathrm{b}}$ & $4.84 \pm 0.19^{\mathrm{c}}$ \\
C-18 (3) & $0.65 \pm 0.21^{\mathrm{a}}$ & $0.79 \pm 0.33^{\mathrm{b}}$ & $0.94 \pm 0.21^{\mathrm{c}}$ \\
C-22 & $0.60 \pm 0.29$ & $0.66 \pm 0.14$ & $0.80 \pm 0.38$ \\
C-24 & $2.33 \pm 0.37^{\mathrm{b}}$ & $2.41 \pm 0.41$ & $1.65 \pm 0.91$ \\
SAFA & $32.89 \pm 0.81^{\mathrm{a}}$ & $30.76 \pm 1.74^{\mathrm{b}}$ & $28.98 \pm 0.67^{\mathrm{c}}$ \\
MUFA & $26.07 \pm 1.26^{\mathrm{a}}$ & $28.84 \pm 2.12^{\mathrm{b}}$ & $31.69 \pm 0.93^{\mathrm{c}}$ \\
PUFA & $4.31 \pm 0.37^{\mathrm{a}}$ & $4.96 \pm 0.45^{\mathrm{b}}$ & $5.78 \pm 0.22^{\mathrm{c}}$ \\
UFA & $30.44 \pm 1.32^{\mathrm{a}}$ & $33.80 \pm 2.43^{\mathrm{b}}$ & $37.47 \pm 1.15^{\mathrm{c}}$ \\
SAFA:UFA & $1.08 \pm 0.06^{\mathrm{a}}$ & $0.91 \pm 0.09^{\mathrm{b}}$ & $0.79 \pm 0.02^{\mathrm{c}}$ \\
\hline
\end{tabular}

Mean with different superscript at the same row differ significantly $(\mathrm{P}<0.05)$.

C-12 = lauric acid; C-14= miristic acid; C-16= palmitic acid; C-16(1)= palmitoleic acid; C $18=$ stearic acid;

C-18 (1)= oleic acid; C-18(2)= linoleic acid; C-18(3)= alpha-linolenic acid; C-22 = behenic acid.;

$\mathrm{C}-24=$ lignoceric acid; $\mathrm{SAFA}=$ saturated fatty acid; $\mathrm{MUFA}=$ mono unsaturated fatty acid; $\mathrm{PUFA}=$ polyunsaturated fatty acid; UFA=unsaturated fatty acid

making cholesterol synthesis inhibited. According to Odle (1997) stated that MCFA had high soluble force and lower digestion enzyme need, making it easy to enter liver through venous without passing through lymph circulation and quickly burnt to be energy. It caused increasing of metabolism in 
body so that fatty acids not deposited in body and not changed into cholesterol.

\section{The Fatty Acid Content of Lamb Meat}

Composition of the fatty acid content of meat is presented in Table 3. Differences in fatty acids occurred in stearic acid (C-18). There was reduction of stearic acid content when animal consumed medium chain fatty acid (MCFA). Stearic acid level reduced in giving 1\% of MCFA in feed, then reduced again when feed increased MCFA content. Change in fatty acids also occured in C-18 unsaturated fatty acids for both MUFA and PUFA. Giving $1 \%$ of MCFA increased oleic, linoleic and linolenic acids, and after adding 1.5\% of MCFA, more increase. The content of SAFA in lamb was reduction when the animals consumed $1 \%-1.5 \%$ of MCFA. Similarly, MUFA and PUFA were change in content after giving MCFA. Content of MUFA and PUFA was increasing. MCFA could increase composition of meat fatty acids especially MUFA and PUFA. Ratio between saturated fatty acids and unsaturated fatty acids showed significant difference. Feed containing 1$1.5 \%$ of MCFA produced more meats containing unsaturated fatty acids (MUFA/PUFA). Whereas treatment of feed which did not contain MCFA produced meats widely containing saturated fatty acids (SAFA).

The increase of meat unsaturated fatty acid content caused by feed treatment (R2 and R3) contains MCFA. Therefore, when MCFA is consumed, propionic acid increased (Tabel 2). The propionic acid played of role on the quality of meat produced. According to Marmer et al. (1985), propionic suppressed rumen biohydrogenase causing unsaturated fatty acids was not degradated in rumen and the unsaturated fatty acids went into the small intestine. The presence of propionic in the rumen not only inhibit the biohydrogenase process in rumen, but also increased the odd-chain fatty acids of intramuscular fat (Duckett et al., 1993).

\section{CONCLUSION}

Methanogenic inhibitor feed with 1.0-1.5\% MCFAcan be used as feed for sheep, and the results showed that the propionic acid content in rumen increased at range of $29.59-36.11 \%$. The cholesterol content decreased at range of 7.14$10.06 \%$. For the meat fatty acids composition, unsaturated fatty acids increased at range of 9.05$17.96 \%$, while saturated fatty acid decreased at range of $6.59-11.88 \%$.

\section{REFERENCES}

AOAC. 2005. Office Methods of Analysis. 15th ed. Association of Office Analytical Chemists, Arlington, VA.

Berg, R.T. and R.M. Butterfield, 1976. New Conceps of Cattle Growth. Sydney University Press, Sydney

Christophersen, C.T., A.D.G. Wright and P.E. Vercoe. 2008. In vitro methane emission and acetate:propionate ratio are decreased when artificial stimulation of the rumen wall is combined with increasing grain diets in sheep. J. Anim. Sci. 86:384-389

Ducket, S.K., L.D. Yates, D.G. Wagner, H.G. Dolezal, M.T. Vankoevering and D.R. Gill. 1992. Effect of laidlomycin propionate on the on the lipid and cholesterol content of beef rib steaks. J. Okla Agr. Exp.Sta.Res.Rep.MP136:23-26

Ducket, S.K., L.D. Yates, D.G. Wagner, H.G. Dolezal, M.T. Vankoevering and D.R. Gill. 1993. Effect of laidlomycin propionate on the fatty acid composition of beef ribeye steaks. J. Anim Sci. p.60-63

Forest, J.C., E.B. Aberle, H.B. Hendrick, M.D. Judge and R.A. Merkel. 1975. Principles of Meat Science. W.H. Freeman and Co., San Fransisco.

Geay, Y., D. Bauchart, J. F. Hocquette and J. Culioli. 2001. Effect of nutritional factors on biochemical, structural and metabolic characteristics of muscles in ruminants, consequences on dietetic value and sensorial qualities of meat. Reprod. Nutr. Dev. 41:126.

Gilka, J., P. Jelinek, B. Jankova, P. Knesel and J. Mašeket. 1989. Amino acid composition of meat, fatty acid composition of fat and content of some chemical elements in the tissues of male lambs fed monensin or lasalocid. Meat Sci. 25:273- 280

Lawrie, R.A. 1979. Meat Science. 2nd ed. Pergamon. Press. Sydney

Lee, J. H., B. Kouakou and G. Kannan. 2008. Chemical composition and quality characteristics of chevon from goats fed three different post-weaning diets. Small Rumin. Res. 75: 177-184.

Madruga, M. S., N. Narain, T. F. Duarte, W. H. de Sousa, M. S. Galvão, M. G. G. Cunha and J. L. F. Ramos. 2005. Chemical and sensorial 
characteristics of commercial meat cuts of "mesticos" and Boer goats. Ciênc. Technol. Aliment. 25:713-719.

Marmer, W.N and R.J. Maxwell. 1985. Effects of dietary monensin on bovine fatty acid profiles. J. Agric. Food Chern. 33:67-72

Martinco, J.M and M.T. Madigan. 2005. Brock Biology of Microorganism, $11^{\text {th }}$ ed. Englewood Cliffs, N.J: Prentice Hall.

Odle, J. 1997. New insights into the utilization of medium chain triglycherides by the neonate: observation from a piglet model. J. Nutrition. 127:1061-1067.

Plumer, D.T. 1987. An Introduction to Practical Biochemistry. 3th ed. McGraw-Hill Book
Company. England. 147-167

Santos, C. L., J. R. O. Perez, C. A. C. da Cruz, J. A. Muniz, I. P. A. Santos and T. R. V. Almeida. 2008. Chemical composition of carcass cuts of Santa Ines and Bergamacia lambs. Ciênc. Tecnol. Aliment. 28:51-59.

Sheridan, R., L. C. Hoffman and A. V. Ferreira. 2003. Meat quality of Boer goat kids and Mutton Merino lambs 1. Commercial yields and chemical composition. Anim. Sci. 76:6371.

Soeparno, 1998. Ilmu dan Teknologi Daging. Gadjah Mada University Press, Yogyakarta.

Steel, R.G.D. and J.H. Torrie. 1980. Principles and Procedures of Statistics. McGraw-Hill -Book Co. Inc. New York. 